\title{
ARE MEN OR WOMEN MORE OVERCONFIDENT IN INVESTMENT DECISION-MAKING?
}

\author{
Khaira Rizfia Fachrudin \\ Doctoral Program of Management Science \\ Faculty of Economics and Business, USU \\ Medan, Indonesia \\ tanyakhaira@gmail.com \\ Prihatin Lumbanraja \\ Doctoral Program of Management Science \\ Faculty of Economics and Business, USU \\ Medan, Indonesia
}

\author{
Isfenti Sadalia \\ Doctoral Program of Management Science \\ Faculty of Economics and Business, USU \\ Medan, Indonesia \\ Arlina Nurbaity Lubis \\ Doctoral Program of Management Science \\ Faculty of Economics and Business, USU \\ Medan, Indonesia
}

\begin{abstract}
Stock investment decisions are actions that will generate the highest expected return. This study aims to determine the influence of gender toward overconfidence and investment decision-making and to test whether there are differences in overconfidence between men and women. The population is investors in the city of Medan, Sample is from investors who are actively investing online incorporated in a securities company located in Medan. This study used primary data by questionnaires with sample consisted of 120 respondents. Data analysis using descriptive statistical analysis, regression and Mann-Whitney Test. The results showed no significant influence with alpha five percent between gender toward overconfidence and investment decision-making; there has influence overconfidence toward investment decision-making. There is no difference in overconfidence between men and women. The result of this research is that securities firms can offer investments with different levels of risk to men and women simultaneously.
\end{abstract}

Keywords-gender; overconfidence; investment decision; investment decision-making

\section{INTRODUCTION}

Individual investors in making decisions take action which will result in the highest expected utility/benefit [1] [2]. Rational investors will analyze the process of making investment decisions. Analyzes conducted among others by studying the company's financial statements, as well as evaluate the performance of the business. The objective is the investment decision taken will provide optimal satisfaction/benefit, where the return on investment becomes an indicator to improve the investment performance for investors.

The decision to invest in the stock market is the decision to buy, sell or retain ownership of shares [3] [1]
[4]. Investment decisions are complex processes that include analysis of several factors and various steps. Investment decision are personal resources and technical factors. Investment decision-making by individual investor is factors such as gender, age, education, income and investment portfolios and others. Investment decision-making is the process of selecting certain alternatives from the evaluation of some of them [5].

Investor behavior on investment decision varies, as in [6] finds biased behaviors such as overconfidence, risk aversion, cognitive dissonance, heuristic representativeness and reflection in investors who make short and long-term investments. References [7] [8] found men investor behavior with overconfidence compared to women investors. Overconfidence is a feeling of self-belief in excess. Overconfident investors overestimate the knowledge they have, underestimate the risks and overestimate the ability to control what happens [7]. Research [9] [10] found that gender does not influence overconfident. In line with [11] that age, gender, experience, past performance and management qualifications.

Reference [12] show that overconfidence investors who believe that the accuracy of their knowledge of the value of a security is greater than it is - trades more shares than rational investors. Research [13] suggest that overconfidence venture capitalists can negatively affect decision-making accuracy. The degree of overconfidence depends on the amount of information, the type of information, and whether the venture capitalist believes that the business will succeed or fail. Reference [14] said that overconfidence investor trade too much and when the expected net profit is negative, men are braver to risk investment than women, because men are more overconfidence than women. Reference [15] found that female investors are careful in making decisions, the analysis shows women are very concerned about all variables associated with investment decisions when 
compared with men. According to [16], men and women are similar in their level of confidence when it comes to financial decisions.

The demographic factor of an investor influences the decision in stock investing. Which includes demographic factors include: gender, age, education level, income level, marital status and others - others. Reference [17] stated that demographic factors (sex, income level) have significant differences in financial behavior. Reference [18] found the different finding, there is no difference in behavioral factors between men and women investors in a stock transactions.

\section{LITERATURE REVIEW}

Demography is about population in a region with its modifying factors (mortality, natality, migration, and distribution). In general, Demography is the study of the problems and conditions of population change or in other words, all things related to the changing components such as birth, death, and migration to produce a situation and composition of the population according to age and gender. According to [19], demography is a scientific study of the population, especially about fertility, mortality, and natality. Demographics include scientific studies of quantity, geographic distribution, population composition, and other demographic characteristics, as well as how these factors change over time.

Overconfidence is an exaggerated feeling of trust. Psychologists have determined that overconfidence causes people to overestimate their knowledge, underestimate risks, the risks and overestimate their ability to control what happens [7]. Overconfidence also affects investors behaving risk, rational investors trying to maximize profits while minimizing risk taken [7]. Overconfidence can also cause investors to bear greater risks in making decisions to invest. The indicators used are investor knowledge, and ability with may help them in investing. According to [20] that: (1) Overconfident investors overestimate their ability to evaluate a company as a potential investment. They can become blind to any negative information that indicate a warning sign when to purchase or sell a stock. (2) Overconfident investors can trade excessively as a result of believing that they possess special knowledge that others don't have. (3) Overconfident investors can underestimate their downside risks, because they either don't know, don't understand, or don't heed historical investment performance statistics. As a result, they can unexpectedly suffer poor portfolio performance. (4) Overconfident investors hold underdiversified portfolios, thereby taking on more risk without a commensurate change in risk tolerance, overconfident investors don't even know that they are accepting more risk than they would normally tolerate.

Reference [21] represent several things that cause investors to buy shares influenced by several things such as the volume of stock trading; return rate; and information, and focus more on corporate data and image than when selling them. Investors buy stocks because they are interested and maybe because their attention is on past performance. Investment decisions should be guided by predefined asset allocation decisions that incorporate an acceptable level of risk for the overall horizon of the investor [22].

According to [23] that investor behavior affect selling or buying at different levels. Individual investors when making sales decisions use smaller attention to investment performance. Low market expectations, considerable market correction, and loss experience also influence selling decision [24].

\section{CONCEPTUAL MODEL AND HYPOTHESES DEVELOPMENT}

Hypothesis 1: There is a significant influence gender toward overconfidence.

Hypothesis 2: There is a significant influence overconfidence toward investment decision-making.

Hypothesis 3: There is a difference in overconfidence between men and women.

Figure 1. The Conceptual Model of Study

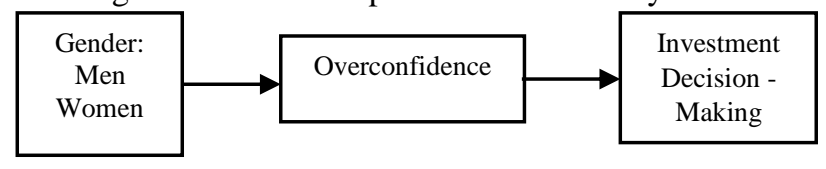

\section{RESEARCH METHODOLOGY}

The population of this research is investors in Medan city - Indonesia, the sample is from the active online investors who joined in some securities company located in Medan. This study uses primary data in the form of questionnaires distributed to investors with the number of 120 returned after being filled by investors and representative on the research location (purposive sampling). Data collection methods are by studying scientific journals, books, internet search, and the questionnare sent to prospected respondents.

Data analysis using descriptive statistical analysis, regression and Mann-Whitney Test. Measurements are with Likert scale. Likert scale is a scale used to measure attitudes, opinions, and perceptions of a person, about a case or social events [25]. Respondents answered the question by choosing from five choices with different scales. In this study used statements with a range of assessment scales are: 1: Strongly Disagree, 2: Disagree, 3: Hesitate 4: Agree, and 5: Strongly Agree. Questions asked to measure investor overconfidence are: investors believe their knowledge of the stock market can help in buying or selling stock decisions (overconfidence 1); investors believe in the competencies they have to invest successfully (overconfidence 2) [26]. Questions to measure investment decision-making are: investors sell stocks when there is high price expectation (investment decision making 1); market correction (investment decision making 2); and small risk of loss (investment decision making 3); investors buy shares when trading levels of large stock volumes (investment decision 
making 4); good return expectation (investment decision making 5); and positive information regarding stock (investment decision making 6) [24].

\section{RESULT AND DISCUSSING}

Table 1 shows the gender percentage of respondents. Respondents amounted to 120 investors from the city of Medan who joined the securities company. In this study $63.3 \%$ of men investors and $36.7 \%$ women investors.

TABLE 1. Demographic Characteristic

\begin{tabular}{|l|c|}
\hline \multicolumn{1}{|c|}{ Gender } & \multicolumn{1}{c|}{ Percent } \\
\hline Men & $63.3 \%$ \\
\hline Women & $36.7 \%$ \\
\hline
\end{tabular}

Respondents' answers are in table 2. The first question on overconfidence, most respondents chose to agree $(45.8 \%)$, and the second question most respondents selected on strongly agree $(42.5 \%)$. The question of investment decision-making are: the first 42 agree, second $31.7 \%$ disagree, the third $30.8 \%$ hesitate, the fourth $38.3 \%$ agree, the fifth $46.7 \%$ agree, and sixth $44.2 \%$ agree.

TABLE 2. Respondents`Answers to Questions Asked via Questionnaire

\begin{tabular}{|l|c|c|c|c|c|}
\hline \multicolumn{1}{|c|}{ Question } & $\begin{array}{c}\mathbf{1} \\
\text { Strongly } \\
\text { Disagree }\end{array}$ & $\begin{array}{c}\mathbf{2} \\
\text { Disagr } \\
\text { ee }\end{array}$ & $\begin{array}{c}\mathbf{3} \\
\text { Hesi } \\
\text { tate }\end{array}$ & $\begin{array}{c}\mathbf{4} \\
\text { Agree }\end{array}$ & $\begin{array}{c}\mathbf{5} \\
\text { Strong } \\
\text { ly } \\
\text { Agree }\end{array}$ \\
\hline $\begin{array}{l}\text { Overconfidence } \\
1\end{array}$ & $0 \%$ & $6.7 \%$ & $\begin{array}{c}21.7 \\
\%\end{array}$ & $45.8 \%$ & $25.8 \%$ \\
\hline $\begin{array}{l}\text { Overconfidence } \\
2\end{array}$ & $2.5 \%$ & $1.7 \%$ & $\begin{array}{c}13.3 \\
\%\end{array}$ & $40.0 \%$ & $42.5 \%$ \\
\hline $\begin{array}{l}\text { Investment } \\
\text { decision making } \\
1\end{array}$ & $0.8 \%$ & $6.7 \%$ & $\begin{array}{c}19,2 \\
\%\end{array}$ & $42.5 \%$ & $30.8 \%$ \\
\hline $\begin{array}{l}\text { Investment } \\
\text { decision making } \\
2\end{array}$ & $20 \%$ & $31.7 \%$ & $\begin{array}{c}29.2 \\
\%\end{array}$ & $16.7 \%$ & $2.5 \%$ \\
\hline $\begin{array}{l}\text { Investment } \\
\text { decision making } \\
3\end{array}$ & $15.0 \%$ & $24.2 \%$ & 30.8 & $23.3 \%$ & $6.7 \%$ \\
\hline $\begin{array}{l}\text { Investment } \\
\text { decision making } \\
4\end{array}$ & $4.2 \%$ & $8.3 \%$ & 27.5 & $38.3 \%$ & $21.7 \%$ \\
\hline $\begin{array}{l}\text { Investment } \\
\text { decision making } \\
5\end{array}$ & & & $\%$ & & \\
\hline $\begin{array}{l}\text { Investment } \\
\text { decision making } \\
6\end{array}$ & $2.5 \%$ & $5.0 \%$ & 22.5 & $44.2 \%$ & $25.8 \%$ \\
\hline & & $1.7 \%$ & 21.7 & $46.7 \%$ & $29.2 \%$ \\
\hline & & & & & \\
\hline
\end{tabular}

TABLE 3. Significant Value Gender Toward Overconfidence

\begin{tabular}{|c|c|c|c|c|c|c|}
\hline \multirow{2}{*}{\multicolumn{2}{|c|}{ Model }} & \multicolumn{2}{|c|}{$\begin{array}{l}\text { Unstandardized } \\
\text { Coefficients }\end{array}$} & \multirow{2}{*}{\begin{tabular}{|c} 
Standardized \\
Coefficients
\end{tabular}} & \multirow[b]{2}{*}{$\mathbf{T}$} & \multirow[b]{2}{*}{ Sig. } \\
\hline & & B & $\begin{array}{c}\text { Std. } \\
\text { Error }\end{array}$ & & & \\
\hline \multirow[t]{2}{*}{1} & (Constant) & 3,892 & ,249 & & 15,663 & ,000 \\
\hline & Gender & 213 & , 171 & ,114 & 1,242 & ,217 \\
\hline
\end{tabular}

There is a significant value of 0.217 indicating that there is no significant influence of gender toward overconfidence.
TABLE 4. Significant Value Overconfidence to Investment Decision-

\begin{tabular}{|c|c|c|c|c|c|c|}
\hline \multirow{2}{*}{} & \multicolumn{2}{|c|}{$\begin{array}{c}\text { Mnstandardized } \\
\text { Coefficients }\end{array}$} & $\begin{array}{c}\text { Standardized } \\
\text { Coefficients }\end{array}$ & & \\
\cline { 3 - 5 } & Model & $\boldsymbol{B}$ & $\begin{array}{c}\text { Std. } \\
\text { Error }\end{array}$ & Beta & \multicolumn{1}{c|}{ T } & Sig. \\
\hline 1 & (Constant) & 4,878 &, 400 & & 12,208 &, 000 \\
\cline { 2 - 5 } & $\begin{array}{l}\text { Overconfi } \\
\text { dence }\end{array}$ &,- 244 &, 093 &,- 234 & $-2,611$ &, 010 \\
\hline
\end{tabular}

There is significant value of 0,010 indicating there is significantly influence overconfidence to investment decision-making.

TABLE 5: Z and Asymptotic Significance Value

\begin{tabular}{|l|r|}
\hline & \multicolumn{1}{|c|}{ Overconfidence } \\
\hline Mann-Whitney U & 1534,000 \\
Wilcoxon W & 4460,000 \\
Z &,- 812 \\
Asymp. Sig. (2-tailed) &, 417 \\
\hline \multicolumn{2}{|c}{} \\
\hline
\end{tabular}

The values of $\mathrm{Z}-0.812$ and asymptotic significance (a probability value test to ensure observed distributions do not deviate significantly from the expected distribution at both ends of the two-tailed distribution) of 0.417 show no difference in men and women overconfidence.

The results of this study obtained some analysis, these are:

- There is no significant influence of gender toward overconfidence. Reference [8] isn't in line with this study that there is a significant influence of gender to overconfidence. In line with [9] [10], as well as [11] shows that gender had no influence toward overconfidence of investors.

- There is a significant influence of overconfidence toward investment decision-making. This research is in line with [20] [12] [14] which found there is significant influence of overconfidence to investment decisionmaking by trading too much stock compared with rational investors. Reference [13] argue that overconfidence influence investment decision-making negatively.

- There is no difference in overconfidence between men and women. This study isn't in line with [14] research suggests men are more overconfidence than women. The findings of [18] are in line with this study that there is no difference in behavioral factors (including overconfidence) between men and women investors in investment decision-making. This study is in line with the study of [16], both gender are similar in their overconfidence. This study shows the existence of gender equality in acquiring knowledge and information that can lead to someone becoming overconfidence. 
VI. CONCLUSION AND RECOMMENDATIONS

Gender has no significant influence on overconfidence with significant value 0.217 . Overconfidence has significant influence on investment decision-making with significant value of 0.010 . No difference between gender in overconfidence with asymptotic significance value 0.417 .

In this era of globalization any gender can obtain information and knowledge to know matters relating to stock investments, make stock investment decisions. This research shows that securities firms can offer investments at different levels of risk to men and women simultaneously.

\section{References}

[1] Z. Puspitaningtyas, "Perilaku Investor Dalam Pengambilan Keputusan Investasi di Pasar Modal," Forum Manajemen Indonesia, pp. 1-19, 2013.

[2] S. J. H. Shahzad, A. Paeman, S. Fawad, A. Sajid, and A. Sehrish, "Stock Market Efficiency: Behavioral or Traditional Paradigm? Evidence From Karachi Stock Exchange (KSE) And Investor Community Of Pakistan," Institute of Interdisciplinary Business Research, vol. 4, no. 10, pp. 605-619, March 2013.

[3] M. Cahyadin, and D. O. Milandari, "Analisis Efficient Market Hypothesis (EMH) di Bursa Saham Syariah," Jurnal Ekonomi Islam, vol. 3, no. 2, pp. 223-236, 2009.

[4] R. Vyas, "Mutual Fund Investor's Behavior and Perception in Indore City," Research World, vol. 3, no. 3, pp. 67-75, 2012.

[5] A. Chandra, "Decision Making in the Stock Market: Incorporating Psychology with Finance," National Conference on Forecasting Financial Markets of India, pp. 1-28, December 2008.

[6] P. Lakshmi, S. Visalakshmi, N. Thamaraiselvan, and B. Senthilarasu, "Assessing The Linkage of Behavioral Traits and Investment Decisions Using SEM Approach," International Journal of Economics and Management, vol. 7, issue 2, pp, 221-241, 2013.

[7] J. R. Nofsinger, The Psychology of Investing, Second Edition, New Jersey: Prentice-Hall Inc, 2005.

[8] G. Bhandari, and R. Deaves, "Demographic of Overconfidence," The Journal of Behavioral Finance, vol. 7, no.1, pp. 5-11, 2006.

[9] D. W. Alrabadi, M.A. Al-Gharaibeh, and Z.M.Zurigat, "What Makes Investors Overconfidence? Evidence From Amman Stock Exchange," European Journal of Economics, Finance And Administrative Sciences, Issue 43, pp. 28-34, 2011.

[10] F. B. Zaidi, and M. Z. Tauni, "Influence of Investor's Personality Traits and Demographic on Overconfidence Bias," Interdisciplinary Journal of Contemporary Research in Business, vol. 4, no. 6, pp. 730-746, October 2012.
[11] Kartini, Setiawan, and A. Dwika, "Faktor - faktor yang mempengaruhi overconfidence investor saham di Yogyakarta," Jurnal Riset Manajemen Priyastiwi Sofiati, vol. 4, no. 1, pp. 36-46, January 2017.

[12] T. Odean, "Are investors reluctant to realize their losses?" Journal of Finance, vol. 53, issue 5, pp. 1775-1798, October 1998.

[13] Zacharakis, L. Andrew, and D. A. Shepherd, "The nature of information and overconfidence on venture capitalists' decision-making," Journal of Business Venturing, vol. 16, issue 4, pp. 311-332, July 2001.

[14] B. M. Barber, and T. Odean, "Boys will be Boys: Gender, Overconfidence, and Common Stock Investment," The Quarterly Jurnal of Economics, pp. 261-292, April 2000.

[15] N. Christanti, and L. A. Mahastanti, "Faktor-Faktor Yang Dipertimbangkan Investor Dalam Melakukan Investasi," Jurnal Manajemen Teori dan Terapan I, Tahun 4, No. 3, pp. 37-51, December 2011.

[16] J. Berggren, and R. Gonzalez, "Gender difference in financial decision making: A quantitative study of risk aversion and overconfidence between the genders," Umea University,pp. 1-55, spring 2010.

[17] V. Andrew, and N. Linawati, "Hubungan Faktor Demografi dan Pengetahuan Keuangan Dengan Perilaku Keuangan Karyawan Swasta di Surabaya," FINESTA, vol. 02, no. 02, pp. 35-39, 2014.

[18] Rr. Iramani, and D. Bagus, "Faktor-faktor Penentu Perilaku Investor dalam Transaksi Saham di Surabaya," Jurnal Aplikasi Manajemen, vol 6, issue 3, pp. 255-262, 2008.

[19] A. Haupt, and T. T. Kane, Population Reference Bureau's Population Handbook, Fourth edition, Eight printing, Printed in the U.S.A., 2000.

[20] M. M. Pompian, Behavioral Finance and Wealth Management, New York: John Wiley \& son Inc, 2006.

[21] T. Odean, "Do Investors Trade Too Much?" Journal of American Economic Review,vol. 89, issue 5, pp. 1279-1298, 1999.

[22] D. D. Winchester, S. J. Huston, M. S. Finke, "Investor Prudence and the Role of Financial Advice, Journal of Financial Service Professionals, vol. 66, issue 4, pp. 43-51, 2011.

[23] B. Barber, and T. Odean, "All That Glitters: The Effect of Attention and News on the Buying Behavior of Individual and Institutional Investors," The Review of Financial Studies, vol. 21, no. 2, pp. 785-818, 2008.

[24] L. P. Luong, and D. T. T. Ha, "Behavioral Factors Influencing Individual Investor's Decision-Making and Performance. A Survey at the Ho Chi Minh 
Stock Exchange," Umea School of Business, pp. 1103, 2011.

[25] Sugiono, Metode Penelitian Kuantitatif, Kualitatif dan R \& D, Bandung: Alfabeta, 2010.

[26] J. H. Park, P. Konana, B. Gu, A. Kumar, R. Raghunathan, "Confirmation Bias, Overconfidence, and Investment Performance: Evidence from Stock Message Boards," McCombs Research Paper Series, no. irom-07-10, pp. 1- 56, July 2010. 